\title{
The changing role of the citizen in conflict reporting
}

\section{ABSTRACI}

New technologies have facilitated the rise of citizen journalism, which promises to dramatically change the role of citizens in conflict reporting from consumers to producers and victims and witnesses to framers and analysts. If this potential is realised, the implications of this new form of journalism are significant, as they stand to challenge the government's traditional role as the dominant source and interpreter of conflicts. This study examines the degree to which the citizen's role has changed in conflict reporting through a comparative analysis of the 2008 Mumbai attacks in the New York Times, New Zealand Herald, London Times and the Times of India. The study finds that the rise of event-driven conflict news reporting offers a limited window of opportunity for non-governmental sources, particularly at the beginning of the conflict, to influence media coverage.

Keywords: citizen journalism, comparative analysis, conflict reporting, foreign policy, non-government sources

\section{BABAK BAHADOR and SERENE TNG University of Canterbury}

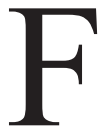
OR four days in November 2008, attacks in Mumbai by the Islamic militant group, Lashkar-e-Taiba, became a media spectacle for the world. The minute news broke, social networking sites like Twitter and Facebook were flooded with a huge volume of messages, turning it into onthe-ground intelligence for mainstream media (Busari, 2008). This included live-blogging offering real-time eyewitness accounts with content originating from Amit Varma, Sonia Falerio, Rahul Bhatia, who were stranded close to Taj Mahal-one of the hotels under siege (Busari, 2008; Mishra, 2008; Amour, 2008). Vinukumar Rangathan, a journalist, also posted some of the first photographs of the attacks on Flickr, a photo-sharing website (Mishra, 2008). International and Indian news organisations quickly featured these 
accounts and images in their news reports, making individuals like Varma and Rangatham media personalities (Mishra, 2008).

The attacks were hailed not just for their military and political significance, but also as a demonstration of the growing importance of citizens in news reporting (Busari, 2008; Mishra, 2008; Amour, 2008; Stelter \& Cohen, 2008; Caufield \& Karmali, 2008; Sreenivasan, 2008). While citizen journalism was not new, the Mumbai attacks substantially raised the profile of this new craft. Citizens were no longer just consuming the news but also producing it and potentially even challenging the government's dominant role as the major source and interpreter of conflicts. This study attempts to assess the influence of citizens as news sources and the degree to which event-driven news enables the inclusion of more non-governmental sources in conflict reporting. Studying the sources of news is important in understanding today's rapidly changing and diversifying news environment (Messner \& Distaso, 2008, p. 449). Sources that manage to get their positions across most prominently in the media are most likely to influence perceptions and gain an advantage in potentially affecting foreign policy processes and outcomes (Nacos, 1994, p. 16).

\section{Citizen journalism: Rhetoric versus reality}

Citizen journalism is defined as the role citizen play in collecting, reporting, analyzing and disseminating news and information (Bowman \& Willis, 2003 , p. 9). In recent years, the quantity and quality of citizen contributions to news stories has moved beyond novelty, allegedly challenging the ways in which journalists and audiences produce and consume news (Sambrook, 2005; Bruns, 2008). The proliferation of the internet, video recorders and digital cameras enable citizens to supply eyewitness accounts that may be difficult for journalists to capture during a conflict, and these contributions become most critical when no journalists are present (Lyon \& Ferrara, 2005, p. 15). Matheson and Allan suggest that citizens are highly valued for their vicarious, intimate and breaking-news accounts (2007, p. 12). One example of a citizen blog that made an impact was Salam Pax's Iraq war blog. His personal, unfiltered accounts of the Iraq war attracted the attention of not only the blogosphere but also the mainstream news media. To readers, Salam Pax's blog and others are more convincing because of their perceived realness, easy intimacy and personal feel as compared to packaged, onesize-fits-all reporting by mainstream news media (Matheson \& Allan, 2007). 
Blogs and other forms of citizen journalism also often offer an alternative perspective, opening up news coverage to multiple viewpoints (Bruns, 2008; Bowman \& Willis, 2003).

Despite this potential, however, many studies have also concluded that citizen influence on mainstream news reporting is not particularly significant (Haas, 2005; Safran, 2005; Ward, 2006; Stabe, 2006; Paulussen \& Ugille, 2008; Hermida \& Thurman, 2008). In general, these studies suggest that the mainstream media's use of citizen sources is limited and cautious. Haas suggests that citizen-generated information in blogs, in particular, does not challenge the discourses of mainstream news media with alternative viewpoints but may in fact mimic them (2005).

At a primary level, the mainstream media appears to use citizen sources more for their firsthand accounts as victims and witnesses than for their opinions and analysis (Cottle, 2000; Lyon \& Ferrara, 2005; Skoler, 2005). Cottle's study (2000) on the citizen's ability to define environmental risk in the media reinforces the use of citizen sources as victims and witnesses. In his study, he characterised the nature of news sources in two dimensions: 'public-private' and 'analytic-experiential'. According to Cottle (2000, p.35, 37), a public comment addresses the world of public affairs, collective concerns, or shared circumstances, and a private comment addresses an individual's own circumstances, familial world or personal relationships. Furthermore, a comment can be characterised as analytic if advancing a rationally engaged point of view and experiential if based on an experience or response that is often emotionally charged. Cottle's study found that over 80 percent of citizen voices were experiential accounts and that citizens were routinely accessed by the media to symbolically represent and embody lay experience as victims or witnesses.

While the internet offers greater avenues for source selection, the credibility of citizen-generated information remains a critical challenge for mainstream media (Safran, 2005; Matheson \& Allan, 2007; Matheson, 2008; Ward, 2006; Stabe, 2006). Matheson and Allan (2009) argue that while eyewitness bloggers gain credibility in conflict reporting through their access, trust is still the most critical factor for audiences. With an increase in information comes the greater need to sort out story cues and meaning from raw, unfiltered information. Keohane and Nye (1998) suggest that in this environment, power will flow to the journalists, experts and story cue-givers that edit and make sense of the volume of information. Among these interpreters, credibility is key. 


\section{International terrorism}

The Mumbai attacks represented to a particular type of conflict-international terrorism. The labeling of any group as 'terrorist' is, of course, politically charged as authorities often call their rivals terrorists to legitimise their own standing and cause. At a minimum, terrorism has the following characteristics: a fundamentally political nature, the unexpected use of violence against seemingly random targets, the targeting of civilians and an act perpetrated by non-state actors (Cronin \& Ludes, 2004, p. 4). According to Stohl (1988, p. 3), terrorism is not simply violence. It includes violent acts intended to influence a wider audience. How the audience reacts is as important as the act itself. Post-September 11 terrorism is more directed by religious fundamentalism (Sandler, 1003, p. 784). Tiffen describes it as much more lethal and borderless in its reach (2006, p. 103). Support is galvanised through organised, interconnected networks using the expression of religious fanaticism, an ideology that is both abstract and unattainable. It makes use of the potent capacity of the media to create the psychological fear of death on a grand scale.

The role of the media is a fundamental aspect of terrorism. Graber (1980, p. 229) describes that when there is a crisis such as a terrorist act, media coverage goes through three stages. In the first, the media serves as the primary information source. The media's key roles are to describe what has happened. Their top priority is to get accurate information, which relieves uncertainty and calms people. In the second stage, media coverage focuses on making sense of the situation. In the third and final stage, which overlaps with the first two, the media make efforts to contextualise the crisis within a larger political and temporal perspective.

\section{Event-driven news}

Event-driven news is the coverage of activities that, at their initial occurrence, are spontaneous, accidental and not managed by the government within institutional settings (Lawrence, 1996; Bennett \& Livingstone, 2003). Event-driven news results from accidents, natural disasters or unanticipated acts of violence. Event-driven news threatens the government's ability to have full control of the political environment. Lawrence (2000, p. 9) explains that in such circumstances, the media serves as an informal screening mechanism for the policy process, a key arena in which competition over problem 
definition is played out. According to Lawrence (1996), event-driven news differs from the indexing of views associated with routine news. As journalists seek to make sense of dramatic events, news routines may extend to underutilised sources and marginalised perspectives, opening up new gates for citizens and other voices with challenging ideas to enter the news.

Bennett, Lawrence and Livingstone (2006, p. 470) suggest that media framing discretion is at its highest in the immediate aftermath of an event, when dramatic imagery can challenge the news management skills of authorities. For this to happen, certain conditions are necessary. The characteristic of the event itself must offer the possibility of challenging framing. Journalists must have marginalised discourse available to them through sources that are actively advancing challenging ideas (Lawrence, 1996, p. 446). Often, however, dramatic events are met by a unified official response, which triggers an indexing norm and reigns in alternative frames introduced by journalists (Lawrence, 1996, p. 446). Event-driven news frames and especially those in matters of high consequence are thus constrained by the deference of mainstream news organizations to political power (Bennett et al., 2006, p. 481). Bennett and Livingstone (2003, p. 375) found that event-driven stories facilitated by technological advancements, as a result, contained substantial government sourcing.

\section{Methodology}

To assess the changing role of citizens in mainstream conflict reporting, news from The New York Times (NYT), The New Zealand Herald (NZH), London Times (LT) and the Times of India (TOI) regarding the Mumbai attacks was analysed from 27 November to 2 December, 2008. This six-day period was chosen to cover the actual event and several days afterwards when the attacks were still on the news agenda, but focus was on analyzing and contextualising the event. The four news organisations selected were all leading Englishlanguage daily newspapers. The print media was chosen as its news reports usually cover issues in greater depth, allowing potential citizen participation in conflict to be reported more fully. The Mumbai case study was selected because of the alleged significant use of citizen sources in news reporting. The print newspaper articles were compiled through the online search engine Dow Jones Factiva, which offered full text articles.

The unit of analysis was the source, defined as any person or entity directly quoted or attributed as a source in the text of the news article 
(Li \& Izard 2003, p. 209). Seven source categories were derived to reflect source usage in the findings: citizens, government, experts, media, foreign, non-governmental groups (NGOs) and the militants. These source categories were developed with reference from Li and Izard (2003), Nacos (1994) and Wigley and Fontenot (2009) source categories.

Citizen sources as defined by Berkowitz (1987) are individuals commenting in their individual capacity who are not associated or represented with any government entities, professional associations or media organisations. As opposed to earlier studies that allocated only one category for citizens, this study divided citizen sources into four sub-categories: Victims/families, witnesses, voxpops and citizen-journalists. Voxpops and citizen-journalist source categories were added to acknowledge the increasingly diversified use of citizens in news stories. Victims/families refer to those directly impacted by the incident either personally or through a family member. Witnesses are those viewing or experiencing the event firsthand as it unfolds. An example of a witness is:

By 5am, Peter Keep, a British entrepreneur, had counted at least 40 dead bodies at Bombay's St George Hospital. 'It's not an experience that will leave me soon,' he said.-The Times, London, 28 November 2008

Voxpops refer to those who have been quoted with opinions about the event but who have not experienced the incident firsthand. An example of a voxpop is:

'In 51 years, I have never seen this kind of thing,' said Dev B. Gohil, a tailor and lifelong Mumbai resident. 'We're scared for ourselves and for our families.'-New York Times, 29 November 2008

Citizen-journalist sources follow the definition of Wigley and Fontenot (2009) in which citizens are sourced from new technology such as blogs, social networking sites like Twitter, phone text messages or any other citizen journalism ventures.

Government sources as defined by Berkowitz (1987) are local government officials and spokespeople elected or apppointed to office in local, state or federal government entities. Foreign sources consist of foreign government officals and their military or police spokespeople. While both local and foreign 
government sources can be grouped together and be considered as the government source, this study will analyse these sources separately as it provides a more accurate perspective on the use of the sources.

The content analysis of news reports measured the frequency, direction and timing of citizen sources. In terms of frequency, the analysis measured the proportion of citizen source used in relation to government and other sources. In terms of timing, the analysis sought to discover when citizen sources were used during the crisis. To compare the use of sources throughout the Mumbai incident including its immediate aftermath, the six-day period was divided into three stages based on Graber's description of the stages of media coverage during a crisis (1980). Based on an initial review, the first two days (27 to 28 November 2008) represented the beginning stage of the crisis. The next two days (29 to 30 November 2008) represented the stage where the media attempted to make sense of the situation. The final two days (1 to 2 December 2008) represented the stage where the media offered context.

In terms of direction, citizen comments in news reports were evaluated based on their nature and frame type. Cottle's (2000) earlier content analysis categories were used to guide the nature analysis, based on the following four categories: private-experiential (Pte/E), private-analytic (Pte/A), publicexperiential (Public/E) and public-analytic (Public/A). Li and Izard's (2003) study was used to guide the identification of six news coverage frame types: political, economy, disaster, human-interest, safety and criminal activities. An additional frame of citizen journalism was also added to this list. To check for intercoder reliability, 21 articles were randomly selected, making up about 10 percent of the sample of 213 articles for a trained coder unfamiliar with this study to review. The intercoder reliability test produced a coefficient of .86 , which exceeded .70 , the minimum requirement for reliability.

\section{Findings}

The findings from this study revealed that citizens were the most frequently used source type. Of the 1,408 sources identified in 213 news articles from all four newspapers, citizen sources led at 33 percent, followed by government sources (29 percent), foreign sources (14 percent) and non-governmental groups (12 percent). Table 1 outlines the use of different source types by newspaper and in aggregate in percentiles. Results demonstrate that citizens were used more heavily in the first few days of the crisis while government 
Table 1: Media coverage of Mumbai attacks: source frequency

\begin{tabular}{|l|c|c|c|c|c|c|c|}
\hline & Citizens & Govt & Experts & Media & Foreign & Militants & NGOs \\
\hline NYT & $28.94^{*}$ & 12.45 & 8.79 & 4.76 & 34.43 & 1.83 & 8.79 \\
\hline NZH & 35.06 & 11.69 & 3.9 & 14.29 & 27.27 & 6.49 & 1.30 \\
\hline LT & 37.72 & 6.23 & 12.8 & 3.11 & 23.18 & 2.08 & 14.88 \\
\hline TOI & 32.25 & 44.47 & 5.59 & 1.82 & 1.69 & 1.85 & 12.22 \\
\hline Total & 32.88 & 28.62 & 7.60 & 3.34 & 13.85 & 2.20 & 11.51 \\
\hline
\end{tabular}

Frequency of sources for each newspaper

* Reflects the proportion of usage of each source in percentage, rounded off to two decimal places.

Table 2: Media coverage of Mumbai attacks: source usage by stage

\begin{tabular}{|l|c|c|c|c|c|c|}
\hline \multirow{2}{*}{} & \multicolumn{2}{|c|}{ Beginning stage } & \multicolumn{2}{c|}{ Making sense stage } & \multicolumn{2}{c|}{ Context stage } \\
\cline { 2 - 7 } & $27 \mathrm{Nov}$ & $28 \mathrm{Nov}$ & $29 \mathrm{Nov}$ & $30 \mathrm{Nov}$ & $1 \mathrm{Dec}$ & $2 \mathrm{Dec}$ \\
\hline Citizens & $45.45^{*}$ & 45.27 & 38.96 & 32.58 & 19.72 & 38.96 \\
\hline Govt & 11.36 & 30.35 & 27.92 & 39.02 & 42.96 & 44.16 \\
\hline Experts & 4.55 & 11.94 & 7.92 & 12.12 & 6.34 & 0 \\
\hline Media & 5.68 & 1.49 & 4.17 & 4.55 & 4.93 & 0 \\
\hline Foreign & 19.32 & 8.46 & 19.58 & 6.82 & 24.65 & 16.88 \\
\hline Militants & 4.55 & 2.49 & 1.46 & 4.92 & 1.41 & 0 \\
\hline NGOs & 9.09 & 12.94 & 13.13 & 6.82 & 23.35 & 14.29 \\
\hline
\end{tabular}

Overall proportion of source usage in three stages of the crisis

Note: Source usage is shown from 27 November 2008 onwards as there were no print reports on 26 November 2008 when the Mumbai attacks occurred.

* Reflects the proportion of source usage in percentage, rounded off to two decimal places.

sources were used more frequently as the crisis progressed. In the first day of the crisis, for example, citizens represented over 45 percent of sources while the government accounted for only 11 percent. By day five, citizen sources had declined to 20 percent of total sources, while government sources had risen to 43 percent. The percentages of different source types over the different stages of this crisis are outlined in Table 2.

It is perhaps not surprising that citizens constituted a fairly high proportion of news sources during the Mumbai attacks, especially in its early phase. According to Lawrence (1996) and Bennett et al. (2006), the greatest media discretion in choice of sources and frames may be at the beginning of an event when the government may not have full control of the situation. The findings from this study demonstrate that a small window of opportunity clearly presented itself in this incident as government sources were obviously 


\begin{tabular}{l} 
Table 3: Media coverage of Mumbai attacks: citizen sources \\
\hline
\end{tabular}

Type of citizen sources for each newspaper.

* Reflects the proportion of usage of each source in percentage, rounded off to two decimal places.

\section{Table 4: Media coverage of Mumbai attacks: source contribution}

\begin{tabular}{|l|c|c|c|c|}
\hline & Pte/E & Pte/A & Public/E & Public/A \\
\hline Citizens & $85.50^{*}$ & 85 & 12.78 & 12.61 \\
\hline Govt & 6.95 & 8.33 & 39.46 & 34.85 \\
\hline Experts & 0 & 0 & 0.67 & 18.21 \\
\hline Media & 0.91 & 0 & 5.16 & 3.68 \\
\hline Foreign & 1.81 & 1.67 & 20.63 & 16.81 \\
\hline Militants & 0.60 & 0 & 3.14 & 2.63 \\
\hline NGOs & 4.23 & 5 & 18.16 & 11.21 \\
\hline
\end{tabular}

Overall contribution of sources for four types of accounts.

* Reflects the proportion of usage of each source in percentage, rounded off to two decimal places.

not expecting this incident and were therefore caught off-guard at the start. With this vacuum, citizens who had access to the event helped fill the gap and provided vital information otherwise unavailable.

The high proportion of citizen sources used, of course, did not mean that citizens determined the framing of the event. The next analysis reviews the degree to which citizens were used in their conventional roles as victims and witnesses versus for their opinions and analysis. As Table 3 demonstrates, citizens were used mostly as victims and witnesses. The majority of citizens featured by the New York Times (80 percent), New Zealand Herald (100 percent) and London Times (92 percent) were either victims or witnesses and were strongly associated with private/experiential ( 86 percent) or private/ analytical accounts ( 85 percent) (see Table 4$)$ and disaster (45 percent) or human-interest frames (62 percent) (see Table 5).

Despite the claims surrounding the role of citizen journalism during the Mumbai attacks, this study found limited evidence of impact on mainstream 
Table 5: Media coverage of Mumbai attacks: coverage frame

\begin{tabular}{|l|c|c|c|c|c|c|c|}
\hline & Disaster & Political & Economy & $\begin{array}{c}\text { Criminal } \\
\text { activities }\end{array}$ & Safety & $\begin{array}{c}\text { Human } \\
\text { interest }\end{array}$ & $\begin{array}{c}\text { Citizen } \\
\text { journalism }\end{array}$ \\
\hline Citizens & $45.22^{*}$ & 12.35 & 0 & 1.67 & 4.40 & 62.35 & 93.75 \\
\hline Govt & 24.02 & 35.59 & 10 & 61.67 & 51.65 & 29.41 & 0 \\
\hline Experts & 2.67 & 16.47 & 42.50 & 3.33 & 6.60 & 1.18 & 6.25 \\
\hline Media & 4.78 & 4.12 & 0 & 3.33 & 0 & 0 & 0 \\
\hline Foreign & 12.36 & 19.71 & 10 & 28.33 & 8.79 & 0 & 0 \\
\hline Militants & 2.25 & 2.94 & 0 & 1.67 & 1.10 & 0 & 0 \\
\hline NGOs & 8.71 & 8.82 & 37.50 & 0 & 27.47 & 7.06 & 0 \\
\hline
\end{tabular}

Type of sources used with each coverage frame.

${ }^{*}$ Reflects proportion of source association with each coverage frame, rounded off to two decimal places.

media news reports. In the four newspapers covered, there were no citizenjournalist sources cited in the London Times or the New Zealand Herald, and only 6 percent of the New York Times and 7 percent in the Times of India citizen sources were citizen journalists. One factor that likely contributed to this was the challenge of verifying of the high volumes of information from these sources, which no doubt add to the workload of journalists who choose to use them (Paulussen \& Ugille, 2008). As such, unlike the traditional victimwitness citizens who were used frequently at the beginning of a crisis, citizenjournalists were used only at the latter stages of the crisis, from 29 November 2008 onwards. This finding indicates that mainstream media journalists may have needed additional time to validate the credibility of citizen-journalist sources and the value of their information. While the use of citizen sources was generally cautious, the findings did show some use of citizen sources beyond their conventional roles, especially in the Times of India. The Times of India used citizen sources widely throughout at all stages of the crisis.

Citizens were the second most frequently used source after the government in relation to public comments with analysis (18 percent), and critical political comments, in particular (29 percent). Even the small proportion of citizen-journalist sources used by the Times of India reflected mainly public/analytical viewpoints. It is interesting to note that while the other three newspapers (New York Times, London Times and New Zealand Herald) relied heavily on victims and witnesses for most of their citizen accounts, more than half of the citizens quoted in the Times of India did not experience the event firsthand, as they were voxpops and citizen-journalist sources. 


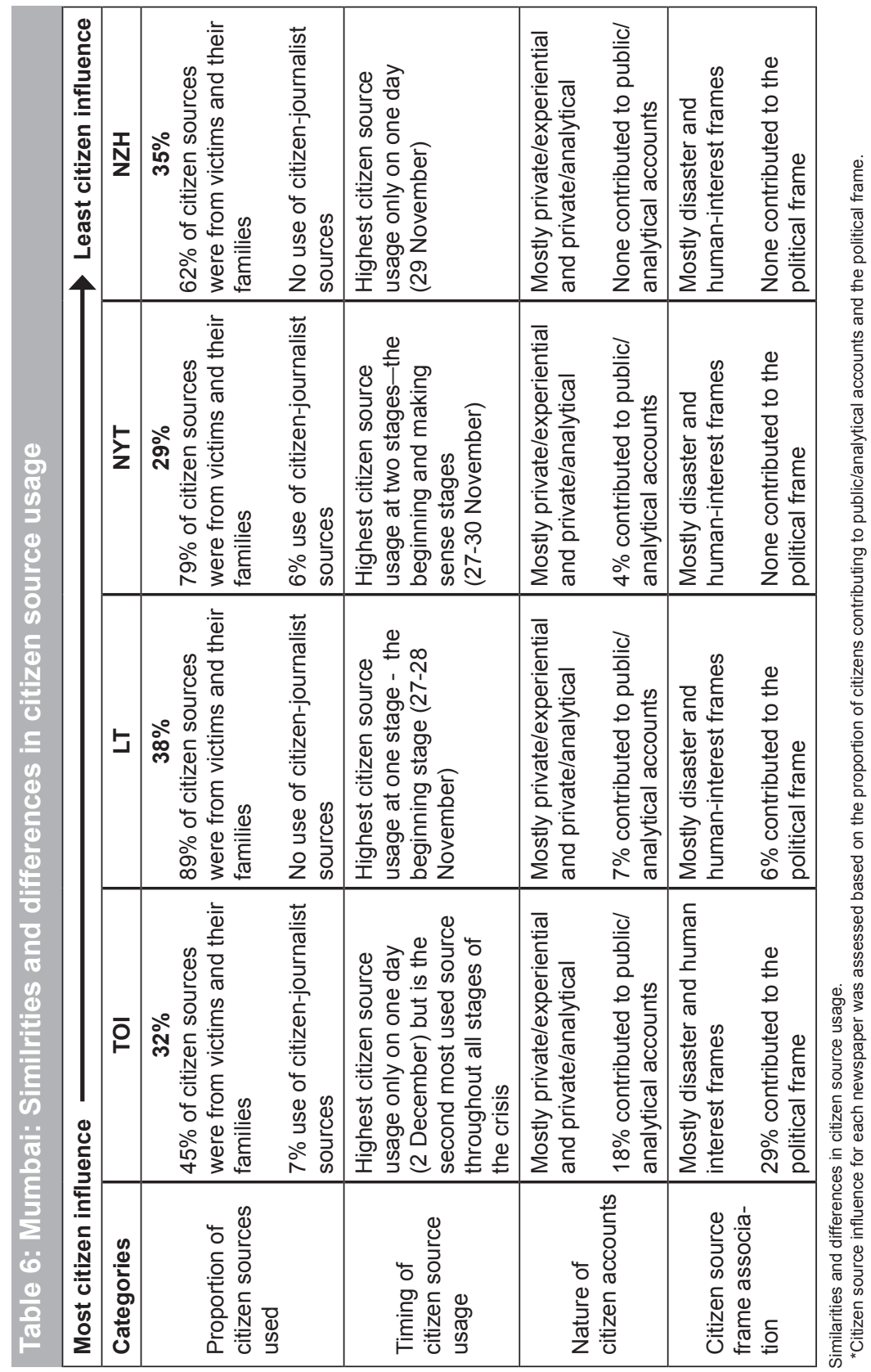

188 PACIFIC JOURNALISM REVIEW 16 (2) 2010 
The use of citizen sources by the Times of India contrasted sharply with the three other newspapers. Citizen sources were limited to the first two days of the Mumbai attacks for the London Times and New York Times. Only a small proportion of citizens contributed to public/analytical ( 7 percent for the London Times and 4 percent for the New York Times) accounts and the political frame (6 percent for the London Times and none for the New York Times). Of the four newspapers, the New Zealand Herald saw the least use of citizen sources beyond their conventional roles. Despite a high proportion of citizen sources used for the New Zealand Herald, no citizen sources were used for public comments (both analytical and experiential) and citizens were only relied upon more on the last day of the attacks on 29 November 2008. Table 6 summarises the similarities and differences in citizen source usage across the four newspapers.

So why were citizen sources in the Times of India able to sustain their voices and offer more critical viewpoints? As Lawrence's event-driven explanation suggests, for underutilized sources like citizens to sustain their voices in event-driven news, certain conditions must be present. The characteristic of the event itself must offer dramatic narrative possibilities and suggest challenging framings of public problems. Journalists must have marginalised discourse available to them through sources that are actively advancing challenging frames and some of the political elite should preferably hold similar views. The Mumbai attacks had all of these conditions. The scale and sophistication of the attacks triggered the need for answers to fundamental questions. While India had a long history of violence, the Mumbai attacks stood out as the most audacious terrorist attacks since September 11. A further analysis of the Times of India reports showed a notable number of citizens offering critical viewpoints on India's security problem. At the same time, politicians from opposition parties were also featured criticising the Indian government for its lax security. According to Bennett (1990) and Hallin (1986), dissensus among the political elite provides the media with an opportunity to provide views critical of the government in the news, reflecting the legitimate political debate taking place in the country. Journalists were more than willing to reflect this wider range of viewpoints in this case, including such views from citizens.

In contrast, an analysis of news reports by the New York Times, London Times and New Zealand Herald found very little conflict between politicians on this issue in their respective countries. In fact, government officials were 
united in denouncing the attacks. This was largely due to the fact that, in contrast to India, this was a foreign policy issue in these other countries - an area that opposition politicians often do not address unless there are important domestic implications. Without political dissent, the media had less incentive to reflect critical discourse and expand the range of voices. This could explain why citizen voices in the New York Times, London Times and New Zealand Herald were both more limited and used primarily as victims and witnesses.

While the findings show that event-driven news enabled greater inclusion of citizen sources, there was also continued heavy reliance on government or foreign sources (foreign government, military and police spokespersons) in all four newspapers. The Times of India relied most heavily on government sources throughout all stages of the Mumbai attacks and used government sources for public comments with analysis and important frames like the political, criminal and safety frames. The other newspapers relied more on foreign sources than their local government sources (see Table 1). Foreign sources were used most frequently in the New York Times and second most often in the London Times and New Zealand Herald. All three newspapers used foreign sources for public comments (experiential and analytical) and political frames. This result, of course, is not surprising given the location of the event.

Analysis of news articles in the Times of India demonstrated that the Indian government became proactive in its attempt to manage the news once the crisis broke. All quotes from Indian officials in the news articles appeared to be from organized press briefings, press statements or updates at the scene of the attacks. Due to the relationship between political power and media access, the political elite will generally still continue to enjoy greater access to the media and dominance of the news agenda. Journalists working with constrains such as deadlines and budgets are also likely to rely more on officials as authoritative sources because of their perceived hierarchy of credibility within the structures of power in society (Manning, 2001).

\section{Conclusion}

This study set out to examine the degree to which the citizen's role has changed in conflict reporting. The findings show that while the media continues to be cautious, using citizens more for their conventional roles as victims or witnesses, there are clear signs of change with some use of both citizen journalism and citizen analytical and political viewpoints present. For the media to use citizens beyond their conventional roles, certain factors must

190 PACIFIC JOURNALISM REVIEW 16 (2) 2010 
be present as suggested by the event-driven hypothesis (Lawrence, 1996). First, the news event has to be spontaneous and dramatic at its initial occurrence. This encourages the media to initially go directly to citizen and other sources to make sense of the situation before the government has the ability to respond and attempt to take control of the flow of information and agenda. Second, the event itself must offer dramatic enough narrative possibilities for citizens to raise compelling and challenging ideas and issues. Third, there must be some political elite support for the challenging framing of the event or issues arising from it for citizens and their ideas to sustain themselves beyond the first stage of the crisis.

The findings from this study contribute to the literature on the relationship of mainstream media news reporting and the government in context of the rise of events-driven news and citizen journalism. As stated by Bennett and his colleagues (2006), what is important for theory building is to understand more precisely the limits of this interdependent relationship and the room provided by events (and other situational factors) for more independent media framing. Event-driven news clearly opens up a small window of opportunity for the media to include a greater diversity of voices in the news.

When it comes to using citizens as sources, credibility is critical and verifying citizen sources remains a constant challenge for the mainstream media. Contrary to the belief that citizen-journalists played an important role in the reporting of the Mumbai attacks, this study found their contribution to be limited compared to other sources. Furthermore, findings showed that the limited role of citizen journalism was not at the beginning of the breaking news story, but rather after several days into the story, presumably allowing time for citizen-journalist sources to be validated. Further research in this area could include additional case studies of conflicts across various media and contexts to test the validity of the findings from this study and establish possible patterns and trends over time.

\section{References}

Althaus, S. L., Edy, J. A., Entman, R. M. \& Phalen, P. (1996). Revising the indexing hypothesis: officials, media, and the Libya crisis. Political Communication, 13(4), 407-421.

Amour, R. D. (2008, November 27). India: covering Mumbai attacks by social media. Global Voices. Retrieved on 17 March 2009, from www.editorsweblog. org/multimedia/2008/11/india_covering_mumbai_attacks_by_social.php 
Bennett, L. W. (1990). Toward a theory of press-state relations in the United States. Journal of Communication, 40(2), 103-125.

Bennett, W.L, \& Livingston, S. (2003). Gatekeeping, indexing and live-event news: is technology altering the construction of news? Political Communication, 20(4), 363-380.

Bennett, L. W., Lawrence, R. G. \& Livingstone, S. (2006). None dare call it torture: indexing and the limits of press independence in the Abu Ghraib scandal. Journal of Communication, 56, 467-485.

Berkowitz, D. (1987). TV news sources and news channels: a study in agenda-building. Journalism Quarterly, 63(2), 508-513.

Bottomley, A. J. (2008). A mediated crisis, news and the national mind. Western Australia: Murdoch University.

Bowman, S. \& Willis, C. (2005). The future is here, but do news media companies see it? Nieman Reports, 59(4), 5-9.

Bruns, A. (2008). Gatewatching, gatecrashing: futures for tactical news media. In B. Megan (Ed.), Digital media and democracy: tactics in hard times (pp. 247-268) Cambridge, Mass.: MIT Press.

Busari, S. (2008, November 28). Tweeting the terror: how social media reacted to Mumbai. CNN. Retrieved on 6 April 2009, from http://edition.cnn.com/2008/ WORLD/asiapcf/11/27/mumbai.twitter/

Caulfield, B. and Karmali, N. (2008, November 28). Mumbai: Twitter's moment. Forbes.com. Retrieved on 27 May 2010 from http://www.forbes.com/2008/11/28/ mumbai-twitter-sms-tech-internet-cx_bc kn1128mumbai.html

Cottle, S. (2000). TV news, lay voices and the visualisation of environmental risks. In Allan S., Adam B. \& Carter, C. (Eds.), Environmental risks and the media (pp. 29-44). London: Routledge.

Cronin, A. K. (2003). Behind the curve, globalisation and international terrorism. International Security, 27(3), 30-58.

Graber, D. A. (1980). Mass media and American politics. Washington, DC: Congressional Quarterly Press.

Haas, T. (2005). From 'public journalism' to the 'public's journalism'? Rhetoric and reality in the discourse on weblogs. Journalism Studies, 6(3), 387-396.

Hallin, D. C. (1986). The uncensored war 1965-1967. The 'uncensored war': the media and Vietnam (pp. 115-157). New York: Oxford University Press.

Hermida, A. \& Thurman, N. (2008). A clash of cultures: The integration of usergenerated content within professional journalistic frameworks at British newspaper websites. Journalism Practice, 2(3), 343-356.

Keohane, R. O. \& Nye, J. S. (1998). Power and interdependence in the information age. Foreign Affairs, 77(5), 81-94.

Li, X. \& Izard, R. (2003). 9/11 attack coverage reveals similarities, differences. Newspaper Research Journal, 24(1), 204-219.

Lawrence, R. (1996). Accidents, icons, and indexing: the dynamics of news coverage of police use of force. Political Communication, 13(4), 437-454. 
Lawrence, R. (2000). The politics of force: Media and the construction of police Brutality. Berkeley \& Los Angeles: University of California Press.

Lyon, S. and Ferrara, L. (2005). With citizens' visual news coverage standards don't change. Nieman Reports, 59(4), 15-16.

Matheson, D. \& Allan, S. (2007). Truth in a war zone: the role of warblogs in Iraq. In Maltby, S. \& Keeble, R. (Eds.). Communicating war: memory, military and media (pp. 75-89). Bury St Edmunds: Arima.

Matheson, D. (2008). Are the new media radically more independent? The International Journal of Communication Ethics, 5(3), 13-16.

Matheson, D. \& Allan, S. (2009). Digital war reporting. Cambridge: Polity Press.

Manning, P. (2001). Considering the powerful and the politically marginal. News and news sources a critical introduction (pp. 137-201). London, California and New Delhi: SAGE Publications.

Messner, M. \& DiStaso, M. W. (2008). The source cycle how traditional media and weblogs use each other as sources. Journalism Studies, 9(3), 447-463.

Mishra, G. (2008). Real time citizen journalism in Mumbai terrorist attacks. Gauravonomics Blog. Retrieved on 27 March 2009, from www.gauravonomics. $\mathrm{com} / \mathrm{b} \log /$ real-time-citizen-journalism-in-mumbai-terrorist-attacks/

Nacos, B. (1994). Terrorism and the media: From the Iran hostage crisis to the Oklahoma City bombing. New York: Columbia University Press.

Nacos, B. (2003). Terrorism as breaking news: attack on America. Political Science Quarterly, 118(1), 23-52.

Paulussen, S. \& Ugille, P. (2008). User generated content in the newsroom: professional and organizational constraints on participatory journalism. Westminister papers in Communication and Culture, 5(2), 24-41.

Safran, S. (2005). How participatory journalism works. Nieman Reports, 59(4), 21-22. Sambrook, R. (2005). Citizen journalism and the BBC. Nieman Reports, 59(4), 12-15. Sandler, T. (2003). Collective action and transnational terrorism. Oxford and Malden, MA: Blackwell Publishing.

Skoler, M. (2005). Fear, loathing and the promise of public insight journalism. Nieman Reports, 59(4), 19-21.

Sreenivasan, S. (2008, December 1). Citizen journalists key in chronicling Mumbai terror attacks. Journalism.about.com. Retrieved on 27 May 2010, from http://journalism.about.com/b/2008/12/01/citizen-journalists-key-in-chronicling-mumbaiterror-attacks.htm

Stabe, M. (2006, March 24). Turning the digital deluge into news. Reporters guide to citizen journalism. Retrieved on 20 June 2009, from pressgazette.co.uk.

Stelter, B. \& Cohen N. (2008, November 29). Citizen journalists provide glimpses of Mumbai attacks. New York Times. Retrieved on 27 May 2010, from http://www. nytimes.com/2008/11/30/world/asia/30twitter.html

Stohl, M. (1988). The politics of terrorism. New York \& Basel: Marcel Dekker.

Tiffen, R. (2006). Contested narratives, ambiguous impacts and democratic dilemmas: the Western news media and the war on terror. Policy and Society, 25(4), 99. 
Vultee \& Wilkins. (2004). News as a public service: thinking through coverage of disasters and terrorism. White paper on disasters and terrorism by Missouri School of Journalism, 1-60.

Ward, M. (2006, March 24). Finding a role in the realm of the bloggers. Reporters guide to citizen journalism. Retrieved on 20 June 2009, from pressgazette.co.uk.

Williams, C. (2004). Terrorism explained. The facts about terrorism and terrorist groups. Sydney, NSW: New Holland.

Wigley, S. \& Fontenot, M. (2009). Where media turn during crises: a look at information subsidies and the Virginia Tech shootings. Electronic News, 3(2), 94-108.

Dr Babak Bahador received his PhD in international relations from the London School of Economics and Political Science in 2005 and lectures in the media, communication and political science programme at Canterbury University's School of Social and Political Sciences. Serene Tng is a public relations practitioner, with ten years of public and private sector experience in Singapore and New Zealand. This article is based on data from her Masters thesis in Mass Communication with the University of Canterbury, completed in 2009. babak.bahador@canterbury.ac.nz

\section{Graduate Diploma in Pacific Journalism}

\section{AUT University 2011}

AUT University's new Graduate Diploma in Pacific Journalism aims to boost the shortage of Pasifika journalists in agrowing and diverse industry in Aotearoa/New Zealand.

It has been created for those wanting to enter the media industry from another career or those already in the industry desiring a qualification. It will also appeal to students and journalists from the Pacific region as well as those in New Zealand.

The core journalism programme is enriched by Pasifika and Mâori and other media elective papers.

Change your life, change your view, and change others.

Visit www.autuni.ac.nz for more information. AUT University, the University for the changing world.

\section{PACIFIC MEDIACENTRE} www.pmc.aut.ac.nz 
Copyright of Pacific Journalism Review is the property of Auckland University of Technology and its content may not be copied or emailed to multiple sites or posted to a listserv without the copyright holder's express written permission. However, users may print, download, or email articles for individual use.

http://www.aut.ac.nz/depts/commstud/journ/pjrsubs.shtml 